\title{
WOLFGANG SACHS
}

Wolpoano SACHS was an Honorary Overseas Member of the Institute, having been elected n 1967. He was born in Posen, a Prussian town, on 23 September 1899, and educated in the Humanistische Gymnasium in Frankfurt am Main, obtaining later, in 1926, the degree of Doctor of Philosophy. He started his business career in 1921 in a now defunct insurance company, Providentia. In 1923 he joined Allianz and spent a year in Johannesburg in the service of the company, leaving later to join Victoria-Versicherungs-Gesellschaften. He served on the Board of that office from 1932 until his retirement in 1966.

He was a gifted linguist, and launched a project for an international five-language Dictionary of Actuarial and Life Insurance Terms which, apart from a wartime break, kept him in continuous contact with a small tean of collaborators from the Institute as well as from European and American actuarial associations. A second edition of the Dictionary appeared in 1964 and a supplement in 1972.

He took a prominent part in the development of a professional body in Germany. Before the second world war, a start was made by creating the Deutsche Aktuarverein. In Germany, AKTUAR retains its medieval connotation (now forgotten in the United Kingdom) as a junior court official. The use of the word in the title, 'Aktuarverein', seemed to militate against the success of this body: at all events it did not long survive and Sachs was a leading figure in the foundation of its successor, the now familiar Deutsche Gesellschaft für Versicherungsmathematik. He served continuously as Senior Vice-President until 1969.

The 1968 International Congress of Actuaries in Munich is well remembered by many members of the Institute. Sachs was in his element as Chairman of the Scientific Committee which chose the subjects and organized the business functions. He was by then widely known and respected, rightfully enjoying the fruits of a lifetime's efforts. Having retired from full-time executive responsibilities, he was able to devote even more energy to furthering the profession. During the period of preparation for the Congress he published in 1967 his book, Erfahrung und Erwartung (Experience and Expectation), which contains a general survey of insurance problens.

He was for many years one of the German members of the Council of the International Actuarial Association and thus known personally to a number of members from the U.K. He was aggressively anglophile, a quality he attributed to the influence of the, in Germany, proverbial Scottish grandmother and he valued highly his honorary membership of the Institute conferred upon him in 1967. The impression he gave was of great energy and determination, but also an indefinable quality of integrity. This quality was perhaps an outcome of his wartime struggles as a scion of mixed, partly Jewish, parentage. His colleague Professor Kracke described Sachs, in a moving tribute, as a patriot and a Calvinist: a man whose love for Germany and its people never faltered. Thanks are due to Professor Kracke for supplying a copy of his address in which he gave details of Sachs' career already mentioned.

The last appearance of Sachs on the international stage was almost dramatic. In poor health, but highly attracted by the occasion, he attended the International Congress in Oslo in 1972 and delivered a spirited attack on certain aspects of the control of life assurance. This was a subject he knew a great deal about as a long-serving member of the German Life Offices Association and an adviser of the control authorities.

He died on 31 August 1974; had he survived a few more weeks, he would have seen yet another project of his come to fulfilment, the publication of a series of actuarial articles which would have commernorated his 75 th birthday.

J HAMILTON-JONES 